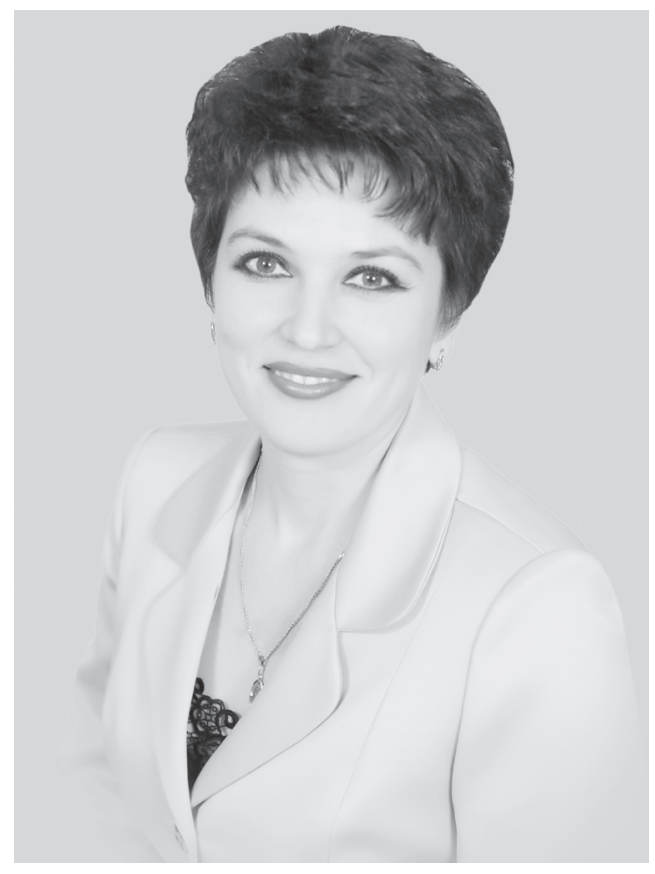

УДК: 316.4

DOI: https://doi.org/10.32689/2617-

2224-2019-18-3-240-251

Корчак Ірина Миколаївна,

аспірант, Національна академія державного управління при Президентові України, 02000, м. Київ, вул. Ежена Потьє, 20, тел.: +3806714778 59, +380674711907, e-mail:ikorchak@gmail.com

ORCID: 0000-0003-3737-5431

Корчак Ирина Николаевна, аспирант, Нащиональная академия государственного управления при Президенте Украины, 02000, г. Киев, ул. Эжена Потье, 20, тел.: +38067 14778 59, +38 06747119 07, e-mail: ikorchak@gmail.com ORCID: 0000-0003-3737-5431

Korchak Irina Mykolaiona, graduate student, National Academy of Public Administration under the President of Ukraine, 02000, Kyiv, Str. Ezhena Potie, 20, tel.: +38067 14778 59, +38067471 1907, e-mail: ikorchak@gmail.com

ORCID: 0000-0003-3737-5431

\title{
СУТЬ I ЗНАЧЕННЯ ПУБЛІЧНОГО КОНФЛІКТУ У СУЧАСНИХ УМОВАХ РОЗВИТКУ СУСПІЛЬСТВА ТА ЙОГО ЗВ'ЯЗОК З АРХЕТИПАМИ КОЛЕКТИВНОГО НЕСВІДОМОГО
}

Анотація. Досліджено сучасну природу соціального конфлікту як об’єкта публічного управління, пошуку більш чіткого й науково обгрунтованого варіанта визначення самого поняття “публічний конфлікт”. У період глобальних перетворень і швидких темпів розвитку суспільства виникають конфлікти, які набувають нових форм, не завжди пов’язаних зі звичним уявленням щодо соціального конфлікту. До того ж в умовах інформатизації та глобалізації значна частина конфліктних ситуацій переходять у відмінну від зазначених форм конфліктів - “публічну”. Автор не просто вводить новий термін - “публічний конфлікт”, а досить революційно (як для конфліктології) обгрунтовує необхідність всебічного дослідження цього явища і надає своє бачення поняттю “публічний конфлікт”. Намагаючись дослідити сутність “публічного конфлікту”, акцентовано увагу на його поширенні у сфері публічного управління і водночас наголошено, що це лише одна із суб'єктивних точок зору, 
яка вимагає належної об’єктивації і вивчення всім зацікавленим науковим співтовариством. Прийнятий умовно в статті термін “публічний конфлікт” найчастіше виникає у сфері публічного управління. Водночас його “раціональна сутність” так чи інакше стосується масової інноваційної активності людей, в результаті якої піддається динамічним перетворенням інституційна сфера суспільного життя, в тому числі інститути держави.

Проаналізовано події останніх років, упродовж яких відбулися радикальні якісні зміни в українському суспільстві. Вони супроводжувалися посиленням конфліктних ситуацій, які багато в чому відбуваються внаслідок суперечливої природи людини, ㄲï самовизначення і самоствердження в процесі конфліктологічної взаємодії. “Активний принцип спадкового” (за К. Юнгом) у цей час працює в українському суспільстві, змущуючи переосмислювати і повертатися до духовних і моральних цінностей українського народу. Спалахи конфліктних ситуацій в Україні свідчать про розширення соціальної бази поляризації суспільства на тлі його різкого розшарування. Тому дослідження сучасних форм конфліктів здатне забезпечити комплексне й універсальне запобігання і вирішення конфліктів у майбутньому.

XXI століття вимагає від особистості глибоких професійних, інформаційних знань, інноваційного таланту, знання нових технологій, вияву таких якостей, як духовність і патріотизм. У цій спрямованості до сталого розвитку суспільства особистість завжди вступає у конфлікт з власним “Я” і громадським "Ми".

Ключові слова: архетипи колективного несвідомого, конфлікт, публічна політика, публічний конфлікт, соціальний конфлікт.

\section{СУЩНОСТЬ И ЗНАЧЕНИЕ ПУБЛИЧНОГО КОНФЛИКТА В СОВРЕМЕННЫХ УСЛОВИЯХ РАЗВИТИЯ ОБЩЕСТВА И ЕГО СВЯЗЬ С АРХЕТИПАМИ КОЛЛЕКТИВНОГО БЕССОЗНАТЕЛЬНОГО}

Аннотация. Исследована современная природа социального конфликта как объекта публичного управления, осуществлялся поиск более четкого и научно обоснованного варианта определения самого понятия “публичный конфликт”. В период глобальных преобразований и быстрых темпов развития общества возникают конфликты, которые приобретают новые формы, не всегда связанные с привычным представлением социального конфликта. К тому же в условиях информатизации и глобализации значительная часть конфликтных ситуаций переходят в другую - отличную от упомянутых форм конфликтов - “публичную”. Автор не просто вводит новый термин “публичный конфликт”, а достаточно революционно (как для конфликтологии) обосновывает необходимость всестороннего исследования этого явления и предоставляет свое видение понятия “публичный конфликт”. Пытаясь исследовать сущность “публичного конфликта”, внимание акцентируется на его влиянии в сфере государственного управления и одновременно подчеркивается, что это лишь одна из субъективных точек зрения, которая требует 
должной объективации и изучения всем заинтересованным научным сообществом. Принятый условно в статье термин "публичный конфликт" чаще всего возникает в сфере публичного управления. Вместе с тем его "рациональная сущность” так или иначе касается массовой инновационной активности, в результате которой подвергается динамическим преобразованиям институциональная сфера общественной жизни, в том числе институты государства.

Проанализированы события последних лет, в течение которых произошли радикальные качественные изменения в украинском обществе. Они сопровождались усилением конфликтных ситуаций, во многом происходящих вследствие противоречивой природы человека, его самоопределения и самоутверждения в процессе конфликтологического взаимодействия. “Активный принцип наследственного” (по К. Юнгу) в настоящее время работает в украинском обществе путем переосмысления и возвращения к духовным и нравственным ценностям украинского народа. Вспышки конфликтных ситуаций в Украине свидетельствуют о расширении социальной базы, поляризации общества на фоне его резкого расслоения. Поэтому исследование современных форм конфликтов способно обеспечить комплексное и универсальное предотвращение и разрешение конфликтов в будущем.

XXI век требует от личности глубоких профессиональных, информационных знаний, инновационного таланта, знания новых технологий, проявления таких качеств, как духовность и патриотизм. В этой устремленности к устойчивому развитию общества личность всегда вступает в конфликт с собственным “Я” и общественным “Мы”.

Ключевые слова: архетипы коллективного бессознательного, конфликт, публичная политика, публичный конфликт, социальный конфликт.

\section{THE ESSENCE AND SIGNIFICANCE OF THE PUBLIC CONFLICT IN THE MODERN CONDITIONS OF DEVELOPMENT OF SOCIETY AND ITS CONNECTION WITH THE ARCHETYPES OF THE COLLECTIVE UNCONSCIOUS}

Abstract. The article is devoted to the study of 'public conflict' in the system of public administration, the search for a more precise and scientifically-based version of the definition of the concept of 'public conflict'. In the period of global transformations and rapid pace of social development, conflicts arise that take on other forms that are not always related to social conflicts. By this time in the scientific literature mainly exploring and defining the conflict provided as social conflict, meets the definition of a political conflict, however, in terms of informatization and globalization a significant part of conflict situations moving to another is different from the above mentioned forms of conflict as 'public form'. In this article, the author not only introduces a new term 'public conflict', but rather revolutionary (as for conflict science as a science), justifies the need for a comprehensive and comprehensive study of this phenomenon and provides his own vision of the definition of 'Public Conflict'. Trying to explore the essence of 'public 
conflict' in the article focuses on its influence in the field of public administration, and simultaneously emphasizes that this is only one of the directions of research, the rest of the same directions need to be added to his study of all interested scientific community. Conditionally accepted in the article the term 'public conflict' often occurs in the field of public administration, especially its study of the sphere of public administration. The rational nature of modern conflicts leads to massive innovative activity, which results in dynamic changes in the institutional sphere of public life, including the institutions of the state.

The article analyses the events of recent years, during which there have been dramatic changes in the Ukrainian society, which were constantly accompanied by the intensification of conflict situations because of the contradictory nature of human life, in which each individual one way or another self-determines and selfasserts in the process of conflict-related interaction throughout life. The 'active principle of the ancestral' (according to K. Yung) is currently operating in Ukrainian society by rethinking and returning to the spiritual and moral values of the Ukrainian people, including hereditary ones. The outbreaks of conflict situations in Ukraine testify to the expansion of the social base, the polarization of society in the face of a sharp stratification. Therefore, research into this article of contemporary forms of conflict will provide comprehensive and universal prevention and resolution of conflicts in the future.

The $21^{\text {st }}$ century requires the personality of profound professional, informational knowledge, innovative skills, knowledge of new technologies, the manifestation of such virtues as spirituality and patriotism. In this dynamic of human progress towards sustainable development of a personality, the person always conflicts with his own 'Self' and the social 'We'.

Keywords: archetypes of the collective unconscious conflict, public policy, public conflict, social conflict.

Постановка проблеми. Економічна глобалізація та поширення інформаційних технологій, створення віртуальних груп за інтересами, нові форми політики ідентичності, центром якої є релігійні переконання, слабкі уряди, відсталі економіки, релігійний екстремізм, диспропорційне зростання чисельності молоді - ці фактори поєднуватимуться, створюючи ідеальні негативні умови для внутрішніх конфліктів у різних регіонах [1, с. 5].

Уникнути конфліктів та їх наслідків неможливо, тому й вивчення конфліктів, зміна форм конфлікту потребує постійного вивчення та моделювання, прогнозування та запобігання.

Аналіз останніх досліджень i публікацій. Аналіз наукових досліджень і публікацій свідчить, що проблемою щодо визначення конфліктів, їх виникнення, розв'язання і запобігання займалось багато науковців 3 різних країн світу та в різні часи. В умовах незалежної України цьому питанню приділяли увагу О. М. Бандурка, В. А. Друзь, Л. М. Герасіна, М. І. Панов, В. Я. Та- 
цій, Ю. М. Тадика, М. І. Пірен та ін.

Зміни, що відбуваються в українському суспільстві, тісно переплітаються 3 розвитком суспільних процесів у світі. В умовах глобалізації світового суспільства з'являються нові виклики, що спричиняють виникнення конфліктів у нових виявах і формах, особливо в умовах інформатизації суспільства. Одна з форм вияву конфлікту на цей час - це "публічний конфлікт”. Вказана форма конфлікту ще досконало не вивчалась, але уже знаходить відображення у надзвичайних ситуаціях, стає фактором впливу на політичні процеси та процеси прийняття рішень у публічному і державному управлінні.

Мета статті. Розкриваючи сутність загального поняття “конфлікт" і розуміння конфлікту в сучасних викликах суспільних змін, дати визначення та сформулювати одну з форм конфлікту, а саме - "публічного", який на сьогодні формує виникнення нових суспільних феноменів і демократичних цінностей. Таке вивчення конфлікту надасть змогу зустріти виклики інформаційного суспільства в умовах глобалізації та знайти шляхи запобігання та вирішення цих конфліктів.

Виклад основного матеріалу дослідження. Термін “конфлікт” походить від латинського слова conflictus - зіткнення. Конфлікти $є$ закономірним явищем, що притаманне будь-якому суспільству, особливо - сучасному. Від адекватного розуміння природи конфлікту та професійного використання сучасних методів публічного управління значною мірою залежить керованість, збалансованість і безконфліктність суспільної системи та її існування.

Конфлікт - зіткнення протилежних інтересів і поглядів, напруження і крайнє загострення суперечностей, що призводить до активних дій, ускладнень, боротьби, що супроводжуються складними колізіями.

Історія розвитку людства з найдавніших часів до наших днів засвідчує, що конфлікти завжди були і будуть. Науки будь-якого профілю (філософія, історія, культура, політологія, світові релігіi) оперують поняттями конфлікту через поняття добра і зла, порядку і хаосу. Наприклад, історики прагнуть виявити причини розвитку й занепаду держав, глибоких криз і тривалого розквіту в житті окремих народів, адже всі ці процеси відбуваються проблемно, конфліктно [1, с. 23].

Над природою конфліктів замислювалися давні філософи - Анаксимандр (бл. 610-547 рр. до н. е.), Геракліт (бл. 530-470 рр. до н. е.), Фома Аквінський (1225-1274), Еразм Роттердамський (1469-1536), Іммануїл Кант (1724-1804), які розглядали конфлікт, що проявлявся як фактор війни, в житті суспільства та геополітичних процесах.

Георг Гегель (1770-1831) писав, що основна причина конфліктів коріниться в соціальній поляризації між нагромадженим багатством, 3 одного боку, і змушеним працювати народом - 3 іншого.

Чарльз Дарвін (1809-1902) запропонував теорію еволюції, основні ідеї якої виклав у праці "Походження видів шляхом природного відбору, або збереження сприятливих порід у боротьбі за життя". Розвиток живої 
природи здійснюється в умовах постійної боротьби за виживання, тобто постійного конфлікту, вважав він [1, c. 24].

Велике зацікавлення серед конфліктологів кінця XIX - початку $\mathrm{XX}$ ст. викликала соціологічна теорія конфліктів, яка знайшла своє відображення в працях: Карла Маркса (1818-1883) - теорія класової боротьби; Г. Ратценхофера (18421904) - теорія конфліктності соціальних відносин. Американський соціолог Вільям Самнер (1840-1910) поклав початок системному вивченню норм соціальної поведінки, внутрішньогрупових і міжгрупових відносин. Німецький соціолог Георг Зіммель (1858-1918) вважається першим, хто запровадив у науковий вжиток термін "соціологія конфлікту".

Теоретичні роздуми Г. Зіммеля поділяли у 20-ті роки XX ст. соціологи чиказької школи, видатними представниками якої були Роберт Езра Парк (1864-1944), Ернест Уотсон Берджесс (1886-1996), Албіон Вудбері Смолл (1854-1926). Вони розглядали соціальний процес в аспекті чотирьох взаємопов'язаних типів взаємодії: змагання, конфлікт, пристосування й асиміляція [2].

Соціологічне значення конфлікту визначав американський соціолог, представник психологізму в соціології А. В. Смолл, який зазначав конфлікт як загальний конфлікт інтересів, де індивіди - продукт боротьби власних інтересів, а суспільство наслідок зіткнення соціальних інтересів [1, с. 27].

У першій половині $\mathrm{XX}$ ст. переважала теорія соціального конфлік- ту. Конфлікт як протилежність між керівною меншістю та керованою більшістю - це вічна істина, що породжує завжди різні конфлікти.

Починаючи із середини XX ст. відбувається активний розвиток науково-практичного осмислення конфліктів.

Проблемам конфліктів були присвячені праці 3. Фрейда, К. Юнга, Е. Берна та ін.

Австрійський психолог Зигмунд Фрейд (1856-1939) створив одну 3 перших концепцій конфліктології теорію психоаналізу. Карл Густав Юнг (1875-1961) заснував школу аналітичної психології, висунув концепцію про існування колективного несвідомого, запропонував типологію характерів особистості, що до певної міри пояснювала поведінку особистості в конфлікті.

Німецький соціолог Ральф Дарендорф та інші науковці узагальнили теорію "конфліктної моделі суспільства”, діалектичну теорію конфлікту, прагнули визначити й показати загальні для всіх суспільних систем причини конфліктів, а також вказати шляхи оптимізації конфліктного процесу.

Р. Дарендорф виокремлював не тільки негативні сторони конфлікту, а й позитивні. Конфлікт, на його думку, може бути джерелом інновацій, соціальних змін. Інший американський вчений М. Амстуті розвинув ідею "корисності" та "негативності" (шкідливості) конфліктів [1, с. 28].

К. Юнг доповнює роботи Фрейда дослідженнями явища синхронії і того, що він називає "колективним несвідомим”. Вчений розглядає синхронію як явище, в якому подія у 
зовнішньому світі значущим чином збігається з психічним станом людини. Це повторювані переживання, що відображаються у випадках, які не підкоряються законам часу, простору і причинності. За визначенням Юнга, це “працююче” в нас колективне несвідоме, передане суспільству від покоління до покоління, акумулює людський досвід. А пам'ять індивіда в якості “активного принципу спадковості складається із пам'яті предків, “невидимих батьків”, чия влада знову народжується разом 3 дитиною”. Останній, звісно ж не знає про ці наслідки. Він лише тільки відчуває, що щось заважає вільному вияву його інстинктів; і він проектує цю внутрішню перепону передусім на батьків, а потім на суспільство [3, c. 16].

На сьогодні дослідження Юнга щодо "активного принципу спадкового" яскраво відображається у соціальному розвитку суспільства та знаходить своє віддзеркалення у суспільних, економічних, політичних процесах, що відбуваються в Україні. 3 розвитком інформаційних технологій ці процеси все більше проходять у публічній площині.

Глобальні зміни, які відбулися в українському суспільстві за останні 25 років, привели до того, що несвідомо сьогодні відтворюється колись втрачений духовний зв'язок української нації із “пам'яттю предків”. Це геть перевертає колишню радянську уяву і систему цінностей у нинішнього "самодостатнього" (атомізованого) українця, якого народила "Помаранчева революція" (2004) i загартував "Майдан Гідності” (20132014). Звісно, що народжені у зазна- чених подіях нові цінності привели та й ще дотепер виявляють неабиякий внутрішній конфлікт у всіх старших вікових когорт суспільства, що з появою на пострадянському просторі феномену “приватного життя” людини переходить у публічну площину і знаходить своє відображення передусім у суспільно-політичних подіях України.

Зруйновані у перебігу суспільнотрансформаційних процесів старі колективні та групові цінності породжують внутрішньоособистісні конфлікти, які доповнює майнове, грошове і соціальне розшарування у суспільстві. Зрештою духовне падіння, руйнація виробничих зв'язків, безробіття тощо - все це зруйнувало колишню цілісність людини як особистості, але й не сприяє відновленню цієї цілісності вже на нових засадах самодостатньої ідентичності й “унікального індивіда”.

Найбільшою проблемою для активної частини населення стало те, що працюючий професіонал не в змозі забезпечити себе і свою сім'ю гідним рівнем життя. Це стерло межу між класами. В українському суспільстві номінально випав середній клас, який існує і розвивається, але матеріально себе не може забезпечити, звідки й виник парадокс “працюючий жебрак”, який має не тільки розвиватися, а й тратити свій час на матеріальне забезпечення свого життя, побуту. Такий стан індивіда породив конфлікт між потребами дійсності й індивідуальними можливостями.

Е. Шостром порівнює ситуацію конфлікту з двопартійною системою демократії: у кожному з нас закладе- 
на така двопартійна система демократії, при якій одна частина у владі, а друга - в лояльній опозиції. Але опозиція може передбачати не тільки контроль і критику, а й жорстоку боротьбу, тобто конфлікт [4, с. 73].

В у мовах такого конфліктного середовища, в якому останні 27 років перебуває суспільна людина в Україні, зародилася система державної влади в особі представників, які прагнуть до самореалізації шляхом матеріального збагачення за рахунок корупційних схем розкрадання державного бюджету, а саме людського суспільного надбання. У таких представників влади, які цілеспрямовані на швидке матеріальне збагачення, стерлися межі духовних та демократичних цінностей, які інтегруються в наше суспільство.

Країну роздирають егоїстичні інтереси як економічного, так і політичного характеру різних угруповань та окремих осіб. Проблема в тому, що формула, яка була визначена ще на старті розбудови незалежної держави, якою керуються й донині, виявилася не тільки помилковою, а й деструктивною, конфліктною. На практиці вона звелася до добре відомого - реформи за рахунок соціальних чинників. Були демонтовані навіть соціальні досягнення, які свого часу запозичили західні країни [5].

Непереборена криза духовності, нові цінності та ідеали не укріпилися на місці розвінчаних, ідея національної державності під впливом політичної боротьби та соціальної напруги, яка набула в окремих регіонах загрозливого рівня, втратила частину своїх прибічників, українська нація залишається неконсолідованою. Си- туацію в Україні на рівні суспільної свідомості можна схарактеризувати скоріш поняттям “громадянське протистояння”, ніж “злагода” і “порозуміння".

Нині у світі потужною тенденцією є орієнтація на загальнолюдські інтереси, рух за громадянські права особистості. У центрі суспільних дискусій опиняються питання відносин між державними і громадянськими інститутами, прозорості влади, чистоти довкілля, соціальної справедливості та ін. У відкритих громадянських суспільствах західного типу проблема соціального захисту зводиться, з одного боку, до забезпечення колективних прав, з іншого - до забезпечення прав їхніх представників.

Українське ж суспільство характеризується загальною соціальною неврівноваженістю, розривом внутрішньосуспільних відносин, напруженістю між населенням і державою, між духовною елітою і народними масами, нескінченними конфліктами всередині політичної еліти. Спалахи конфліктних ситуацій в Україні свідчать про розширення соціальної бази як ультраправих, так і ультралівих сил, поляризацію суспільства на грунті різкого розшарування, насамперед майнового, між соціально незахищеними верствами населення та владними структурами, що в критичній ситуації несе загрозу суспільного вибуху, дає підстави для діяльності різних політичних спекулянтів.

Люди, які знаходяться у стані внутрішньоособистого конфлікту, є потенційно небезпечними для міжособистісних відносин у групі, 
оскільки негативні наслідки конфлікту чреваті стресами, неврозами, підвищеною тривожністю, загальною психологічною пригніченістю людини або надмірною агресивністю, можуть бути спрямовані на об'єкти, що не мають відношення до конфлікту. А якщо мати на увазі тих, хто займає високі пости у суспільстві, то вони можуть чинити негативний вплив і на відносини більшого масштабу. Наслідки внутрішніх конфліктів найчастіше призводять до зниження продуктивності праці, аварій і техногенних катастроф. Можливість реалізації своїх внутрішніх потреб i бажань зменшить кількість конфліктних ситуацій у суспільстві, що є показником життєздатності самої системи [6, с. 48].

Такі внутрішні конфлікти не дають можливості сучасному розвитку демократичного суспільства в Україні. Конфлікти особисті у суспільному середовищі не давало змоги реалізовувати реформи на державному і місцевих рівнях. Службовці весь час перебували у стресах виборів, що призводили до змін у ключових посадах на “своїх", які також прийшовши до влади, розуміли, що вартість зайнятої посади потрібно компенсувати, і за можливості доступу до державно-суспільного ресурсу $є$ нагода до швидкого матеріального збагачення. За таких умов дуже розвинений державно-політичний конфлікт, який спричинив розвиток і процвітання трудових конфліктів у державному управлінні, небажання державних службовців щось змінювати та змінюватись самим в умовах транснаціонального розвитку світового суспільства.
Такі конфлікти вийшли за межі державного управління і все більше набирають ознак публічних конфліктів, оскільки з розвитком громадянської самосвідомості та громадянського суспільства в Україні, при швидкому розвитку інформаційного ресурсу, питання публічного та державного управління переходять у широкий формат публічності.

Через розвиненість інформаційних технологій та транснаціональних перетворень, які відбуваються у світі, людина як індивід ще більше зросла $і$ потребує самовираження, самореалізації і визнання себе як особистості.

Такі події в українському суспільстві ще більше поглиблюють внутрішньоособистий конфлікт самого індивіда, джерелом якого є сфера проживання. Такі дослідники, як М. Бакунін, П. Сорокін стверджували про необхідність пристосування соціального середовища до потреб особистості, реалізації принципу свободи людини і приведення у відповідність потреб людини з можливістю їх задоволення [7].

Але не в усіх індивідів самовираження носить добрий намір, найчастіше люди хочуть таким чином вплинути на прийняття рішень державовладців з метою виторгу своїх преференцій та досягнення матеріальних інтересів. Тому при такому розвитку публічності важливо якнайбільше в країні проводити політику “з розвитком духовних цінностей” та реалізовувати систему демократичних цінностей.

Яскравим прикладом публічного конфлікту в Україні є проведені вибори Президента України у 2019 р., що показали, як конфлікт стає пу- 
блічним, вийшовши за межі державного управління на міжнародний рівень у формі публічного конфлікту - боротьба за владу, державну владу і міжнародний вплив. В. Зеленський викликав діючого президента Порошенка вийти на публічні дебати. Такої швидкої реакції на публічний виклик у П. Порошенка до цього не було. Чекали від нього публічну реакцію під час захвату українських моряків, а її не було. А тут серйозний поштовх - боротьба за владу став викликом і перейшов у публічний конфлікт, відкриту конфронтацію і потребував відповідної реакції - прийняти участь у передвиборних президентських дебатах. Так ми будемо спостерігати одну із форм розв'язання конфлікту - президентські дебати. Отже, на сьогодні ми маємо нову форму конфлікту - публічний, який є відображенням настроїв суспільства, потреби волевиявлення особистості - індивіда, бажання приймати рішення у публічному управлінні, загострене відчуття справедливості, рівності прав і свобод особистості у суспільному розвитку.

Зворотного шляху у нас немає, процес суспільних змін вже не зупинити, і завдання українського політикуму полягає в тому, щоб перевести його в цивілізоване річище з осмисленою стратегічною перспективою для України. Крім того, європейська приналежність України визначає їі розвиток саме на засадах громадянського суспільства. Саме Держава має, передусім, забезпечувати права своїх громадян та їх соціальний захист, а нові засади її адміністративної та структурної побудови - забезпе- чити максимальне зменшення корумпованості та клановості.

Психологічним підгрунтям для стримування соціального вибуху має бути певний рівень толерантності, терпимості щодо представників різних соціальних груп. У контексті перспектив розвитку держави і суспільства толерантність має розглядатися не тільки як потенціал підтримання миру та спокою в країні, але і як показник ступеня готовності масової свідомості населення до відкритості та взаємоспівробітництва на принципах соціальної справедливості. Це акумулює людський досвід від покоління до покоління, про які в своїх працях писав К. Юнг.

Висновки. Публічний конфлікт - це іманентно притаманний і невичерпний у своїх пізнавальних можливостях об'єкт уваги з боку суспільства. Його коріння лежать у двоїстій природі людини, яка розвивається не менш швидко, як і сама людина, ïï суспільне оточення і людство загалом.

Сучасний - інформаційний етап розвитку людства розширює межі людської природи, ноосферний вимір якої актуалізує архетипний потенціал колективного несвідомого у проблемі вирішення соціальних конфліктів.

Надійними ідеями, методологією й інструментами вирішення конфліктів у сучасному - постмодерному світі цілком можуть стати засади, що іх розпочали будувати Зигмунд Фрейд і особливо Карл Юнг, який зосередив увагу на феномені колективного несвідомого як осереддя єднання “атомізованого” світу сучасної людини. 


\section{СПИСОК ВИКОРИСТАНИХ ДЖЕРЕЛ}

1. Пірен М. І. Конфліктологія: підручник. - К.: МАУП, 2003. - 360 с.

2. Стратегії розвитку України: теорія і практика / за ред. О. С. Власюка. К. : НІСД, 2002. - 864 c.

3. Одайник В. Психология политики: Политические и социальные идеи Карла Густава Юнга / В. Одайник. СПб.: Издат. группа "Азбука-классика", 2010. - 256 с.

4. Шостром Э. Человек-манипулятор. Внутреннее путешествие от манипуляции к актуализации. М.: Апрель-Пресс, Психотерапия, 2008. - 192 c.

5. Кучма Л. Україна на порозі XXI століття: уроки реформ та стратегія розвитку // Матеріали наукової конф. - К.: НТУ КПІ, 2001. - С. 11.

6. Халин К. Е., Климова Ю. В., Левкина Е. В., Богатырева Н. А. Конфликтология. - М.: Экзамен, 2009. 237 c.

7. Бакунин М. А. Избранные философские сочинения и письма. - М.: Мысль, 2003. - 573 с.

8. Аниупов А. Я., Шипилов А. И. Конфликтология: учеб. для вузов. 3-е изд. - СПб.: Питер, 2007. $496 \mathrm{c}$.

9. Ващенко И. В. Общая конфликтология. - Харьков, 2001. http:// www.economics.com.ua/writer/3996/ textbook/11560/tyurina_va/ konfliktyi_i_upravlencheskaya_ deyatelnost/read 6

10. Дмитренко М. Політична система України: розвиток в умовах глобалізації i інформаційної революції: монографія / М. А. Дмитренко. - К.: УН-т "Україна", 2011. $820 \mathrm{c}$.

11. Дмитренко M. Інноваційні стратегії розвитку України: політологічний концепт: монографія
М. А. Дмитренко. - К.: УН-т "Україна”, 2010. - 504 c.

12. Ситник Г. П. Захист національних інтересів - пріоритет профі / Г. П. Ситник // Нар. армія. 2009. - № 51. - C. 5.

13. Україна: стратегічні пріоритети. Аналітичні оцінки - 2004 / ред. кол.: А. С. Гальчинський, О. С. Власюк, 3. С. Варналій та ін. - К.: НІСД, 2004. - 169 c.

\section{REFERENCES}

1. Piren, M I. (2003). Konfliktolohiia [Conflictology]. Kyiv: MAUP [in Ukrainian].

2. Vlasiuka O. S. (Eds.). (2002). Stratehii rozvytku Ukrainy: teoriia i praktyka [Strategy of Ukraine's Development: Theory and Practice]. Kyiv: NISD [in Ukrainian].

3. Odaynik V. (2010). Psikhologiya politiki: Politicheskie i sotsialnye idei Karla Gustava Yunga [Psychology of politics: Political and social ideas of Carl Gustav Jung]. Saint Petersburg: Izdatelskaya gruppa "Azbuka-klassika" [in Russian].

4. Shostrom E. (2008). Chelovek-manipulyator. Vnutrennee puteshestvie ot manipulyatsii $\mathrm{k}$ aktualizatsii [Manmanipulator. Internal travel from manipulation to actualization]. Moscow: Aprel-Press, Psikhoterapiya [in Russian].

5. Kuchma L. (2001). Ukraina na porozi XXI stolittia: uroky reform ta stratehiia rozvytku [Ukraine at the dawn of the $21^{\text {st }}$ century: lessons of reform and development strategy]. Materialy naukovoi konferentsii - Materials of the scientific conference. Kyiv: NTU KPI [in Ukrainian].

6. Khalin K. E., Klimova Yu. V., Levkina E. V., Bogatyreva N. A. (2009). Konfliktologiya [Conflictology]. Moscow: Ekzamen [in Russian]. 
7. Bakunin M. A. (2003). Izbrannye filosofskie sochineniya i pisma [Selected philosophical writings and letters]. Moscow: Mysl [in Russian].

8. Antsupov A. Ya., Shipilov A. I. (2007). Konfliktologiya [Conflictology]. ( $3^{\text {rd }}$ ed.). Saint Petersburg: Piter [in Russian].

9. Vashchenko I. V. (2001). Obshchaya konfliktologiya [General conflictology]. Kharkov. Retrieved from http:// www.economics.com.ua/writer/3996/ textbook/11560/tyurina_va/ konfliktyi_i_upravlencheskaya_deyatelnost/read [in Russian].

10. Dmytrenko M. (2011). Politychna systema Ukrainy: rozvytok $\mathrm{v}$ umovakh hlobalizatsii i informatsiinoi revoliutsii [Political System of Ukraine: Development in the Conditions of
Globalization and Information Revolution]. Kyiv: Universytet "Ukraina" [in Ukrainian].

11. Dmytrenko M. A. (2010). Innovatsiini stratehii rozvytku Ukrainy: politolohichnyi kontsept [Innovative Strategies for the Development of Ukraine: Political Science Concept]. Kyiv: Universytet "Ukrainy" [in Ukrainian].

12. Sytnyk H. P. (2009). Zakhyst natsionalnykh interesiv - priorytet profi [Protection of national interests - pros' priority]. Nar. armiia - People's army, 51, 5 [in Ukrainian].

13. Halchynskyi A. S., Vlasiuk O. S., Varnalii Z. S. et. al. (Eds.). (2004). Ukraina: stratehichni priorytety. Analitychni otsinky - 2004 [Ukraine: Strategic Priorities. Analytical assessments 2004]. Kyiv: NISD [in Ukrainian]. 